\title{
Interaction between diet and gastrointestinal endocrine cells (Review)
}

\author{
MAGDY EL-SALHY ${ }^{1-3}$, TAREK MAZZAWI ${ }^{2,3}$, TRYGVE HAUSKEN ${ }^{2,3}$ and JAN GUNNAR HATLEBAKK ${ }^{2,3}$ \\ ${ }^{1}$ Section for Gastroenterology, Department of Medicine, Stord Helse-Fonna Hospital, 5409 Stord; \\ ${ }^{2}$ Section for Gastroenterology, Department of Clinical Medicine, University of Bergen, 5020 Bergen; \\ ${ }^{3}$ Department of Medicine, National Centre for Functional Gastrointestinal Disorders, \\ Haukeland University Hospital, 5021 Bergen, Norway
}

Received January 29, 2016; Accepted March 1, 2016

DOI: 10.3892/br.2016.649

\begin{abstract}
The gastrointestinal endocrine cells are essential for life. They regulate the gastrointestinal motility, secretion, visceral sensitivity, absorption, local immune defense, cell proliferation and appetite. These cells act as sensory cells with specialized microvilli that project into the lumen that sense the gut contents (mostly nutrients and/or bacteria byproducts), and respond to luminal stimuli by releasing hormones into the lamina propria. These released hormones exert their actions by entering the circulating blood and reaching distant targets (endocrine mode), nearby structures (paracrine mode) or via afferent and efferent synaptic transmission. The mature intestinal endocrine cells are capable of expressing several hormones. A change in diet not only affects the release of gastrointestinal hormones, but also alters the densities of the gut endocrine cells. The interaction between ingested foodstuffs and the gastrointestinal endocrine cells can be utilized for the clinical management of gastrointestinal and metabolic diseases, such as irritable bowel syndrome, obesity and diabetes.
\end{abstract}

\section{Contents}

1. Introduction

2. Gastrointestinal endocrine cells

3. Interaction between diet and gastrointestinal cells

4. Conclusion

\section{Introduction}

An intake of nutrients is essential for maintaining life, as they provide energy to the body, and also trigger other

Correspondence to: Professor Magdy El-Salhy, Section for Gastroenterology, Department of Medicine, Stord Helse-Fonna Hospital, P.O. Box 4000, 5409 Stord, Norway

E-mail: magdy.el-salhy@helse-fonna.no

Key words: diet, endocrine cells, gut, microbiota, paracrine important body functions. The interaction between ingested foodstuffs and the gastrointestinal endocrine cells is a new emerging concept $(1,2)$. Understanding this interaction is not only important for understanding the normal physiology and the role of ingested nutrients in gastrointestinal disorders and diseases, but also for managing certain gastrointestinal disorders (3-6).

New data on the interaction between ingested nutrients and the gastrointestinal endocrine cells obtained from basic science and clinical research have accumulated in the last few years. The present review aimed to interpret the newly gained knowledge so as to understand the role of this interaction.

\section{Gastrointestinal endocrine cells}

General. The gastrointestinal endocrine cells are scattered between the mucosal epithelial cells facing the intestinal lumen (Fig. 1) (7,8). There are $\geq 10$ types of endocrine cell, and they are found in the stomach and the small and large intestines (8). Different segments of the gastrointestinal tract contain several different populations of gut endocrine cells (Fig. 2). Certain types of endocrine cells are located only in specific areas of the gastrointestinal tract. For example, serotonin- and somatostatin-secreting cells occur in the stomach and small and large intestines, while those producing ghrelin and gastrin are found only in the stomach, those producing secretin, cholecystokinin, gastric inhibitory peptide (GIP) and motilin are found only in the upper small intestine, and those producing polypeptide YY (PYY), pancreatic polypeptide and oxyntomodulin are located only in the lower small intestine and large intestine (7,9-11). The densities of these cells vary in different sections of the gastrointestinal tract, with the density being highest in the duodenum (12-16) (Fig. 3). The gastrointestinal endocrine cells regulate gastrointestinal motility, secretion, absorption, visceral sensitivity, local immune defence, cell proliferation and appetite (7,17-31). These endocrine cells interact with each other and also with the enteric nervous system, and the afferent and efferent nerve fibers of the autonomic nervous system and the central nervous system (CNS) $(7,18,22,32)$. Depletion of gastrointestinal endocrine cells as in congenital malabsorptive diarrhea caused by mutant neurogenin-3 (33), or complete loss of these cells in mutant 


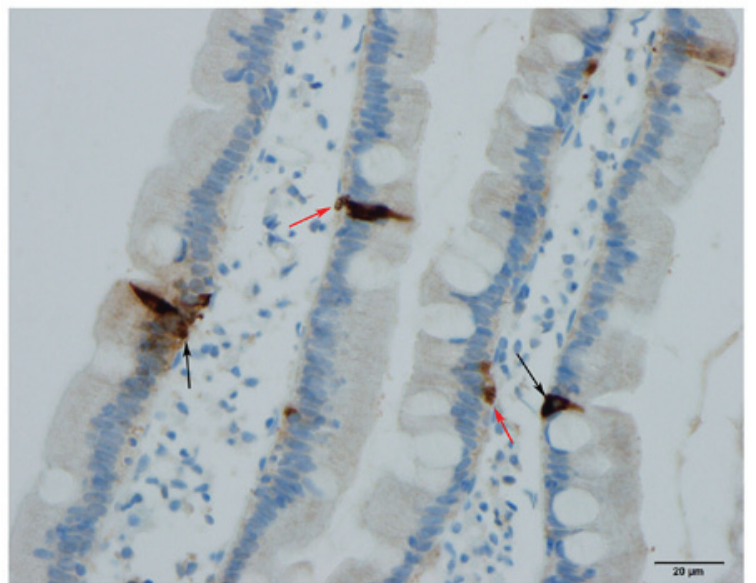

Figure 1. Gastrointestinal endocrine cells are scattered between the epithelial cells lining the gastrointestinal lumen (black arrows). A basal cytoplasmic process can occasionally be observed (red arrow). Chromogranin A cells in human duodenum.

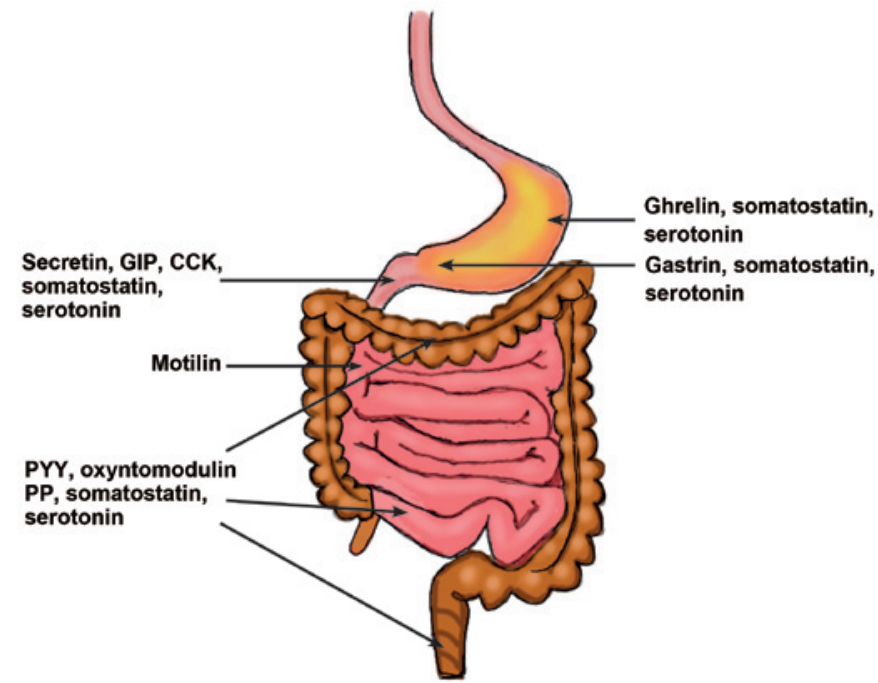

Figure 2. Distribution of different gastrointestinal endocrine cells in the gastrointestinal tract.

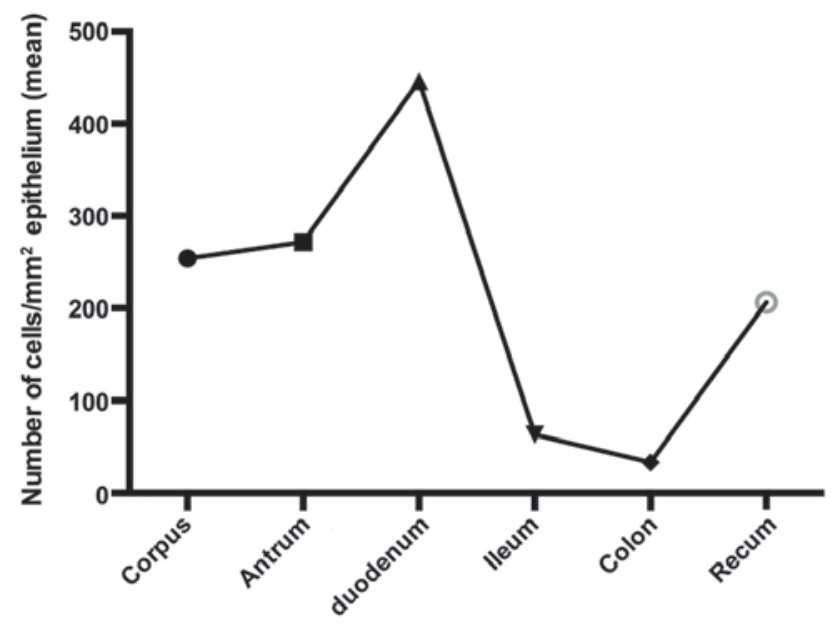

Figure 3. Densities of endocrine cells in different segments of the gastrointestinal tract as detected by chromogranin A. These segments were immunostained using the same method and the same antibody, and were quantified in the same way in the same laboratory by a single person (12-16).

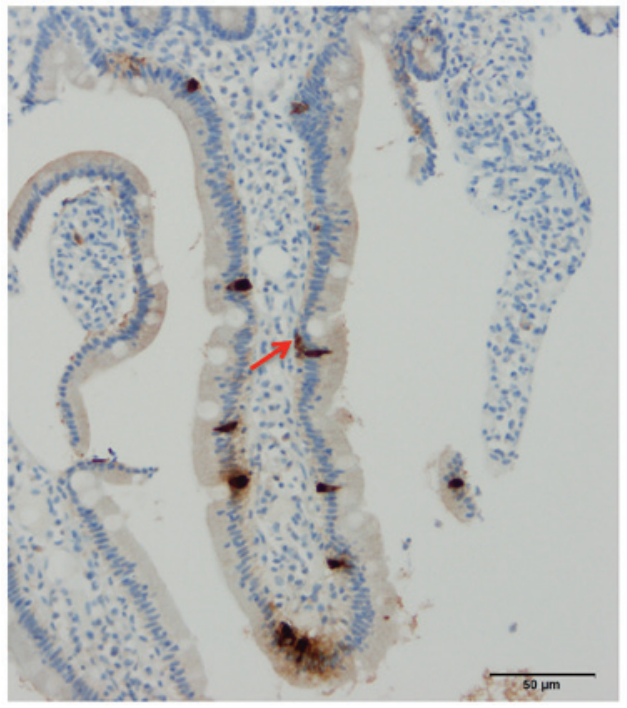

Figure 4. Human duodenal secretin cells. Some of these cells possess a basal cytoplasmic process parallel to the basement membrane (arrow).

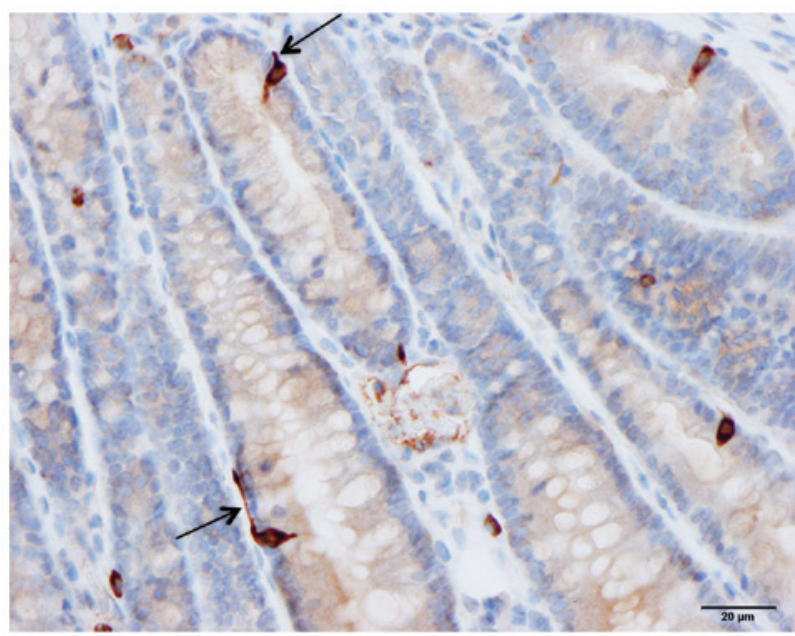

Figure 5. Polypeptide YY cells in the colon of a rat. These cells possess a cytoplasmic process (arrow) similar to that observed in the human small intestine.

mice with ablation of the transcript factor neurogenin-3 (34) show that the gastrointestinal endocrine cells are essential for life.

Immunohistochemical studies have shown that two hormones can be colocalized in the same endocrine cell type, such as glucagon-like peptide-1 and GIP in the small intestine as well as PYY and oxyntomodulin in the large intestine (34-38). Recent studies have further found that mature intestinal endocrine cells are capable of expressing several hormones $(39,40)$.

Gastrointestinal endocrine cells as sensory cells. The gastrointestinal endocrine cells have specialized microvilli that project into the lumen and function as sensors of the gut contents (mostly nutrients and/or bacteria byproducts), and respond to luminal stimuli by releasing their hormones into the lamina propria (41-63). The gut intraluminal contents of carbohydrates, proteins and fats trigger the release of different 
Table I. Hormones released from the gastrointestinal endocrine cells depending on the gastrointestinal luminal contents of carbohydrates, proteins and fats.

Gastrointestinal nutrients

Process Carbohydrates Proteins Fats

$\begin{array}{llll}\text { Hormones released } & \begin{array}{l}\text { Gastric inhibitory polypeptide } \\ \text { and oxyntomodulin }\end{array} & \begin{array}{l}\text { Pancreatic polypeptide, neuropeptide Y, } \\ \text { motilin, ghrelin, and cholecystokinin (CCK) }\end{array} & \text { motilin, ghrelin, and CCK }\end{array}$

\section{Lumen}

\section{Endocrine cell}

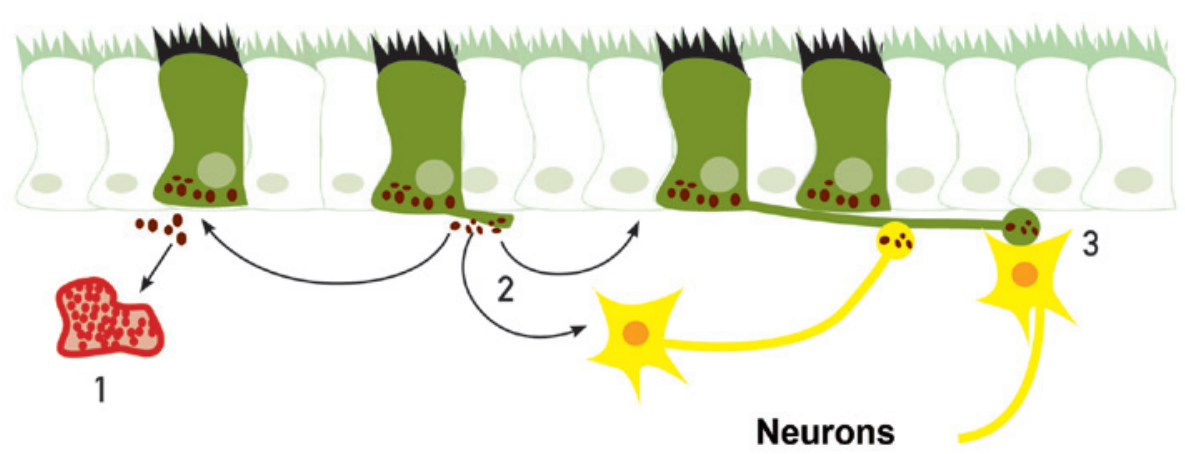

Figure 6. Gastrointestinal endocrine cells may exert their effects via three modes of action: 1, By entering the circulating blood and reaching distant targets (endocrine mode); 2, by acting locally on nearby structures (paracrine mode); or 3, via synaptic activity.

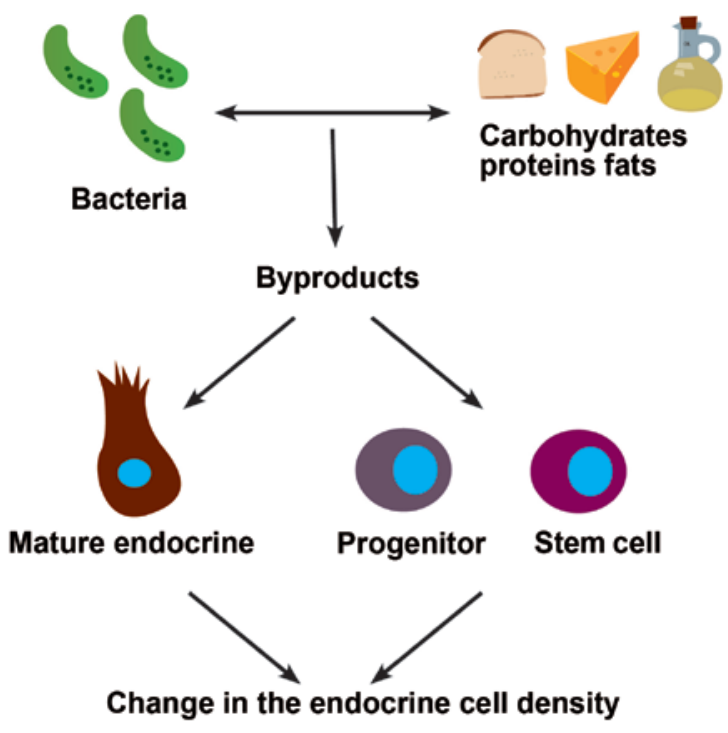

Figure 7. Schematic illustration of the possible ways by which a change in diet could affect the density of gastrointestinal cells.

signaling substances (such as hormones) from the gut endocrine cells (Table I) (41-53).

Mode of action of gastrointestinal endocrine cells. The signaling substances (hormones) released from the gastrointestinal endocrine cells may exert their actions locally on nearby cells or neurons (paracrine mode) or by entering the circulating blood and reaching distant targets (endocrine mode) (64-67).
The gastrointestinal endocrine cells possess a basal cytoplasmic process, which is believed to facilitate the paracrine mode of action (Figs. 4 and 5) (68-72). This cytoplasmic process extends $\leq 70 \mu \mathrm{m}$, compared with the base of the endocrine cells being only $10 \mu \mathrm{m}$ in diameter (70). This process has certain similarities to neuronal axons, and has been named a neuropod (70,73-75). The neuropod has other axon-like characteristics, such as containing neurofilaments, being escorted by enteric glia cells, and expressing receptors for neurotrophins (74). Furthermore, gut endocrine cells have small clear synaptic vesicles, express several genes encoding for presynaptic proteins (synapsin 1, piccolo, bassoon, MUNC13B, regulating synaptic membrane exocytosis 2, latrophilin and transsynaptic neurexin), and also express postsynaptic genes (transsynaptic neuroligins 2 and 3, homer 3 and postsynaptic density 95) (75). Based on these data, it was concluded that the gut endocrine cells have the necessary elements for afferent and efferent synaptic transmission (75). Therefore, it appears that the gastrointestinal endocrine cells exert their effects via three modes of action: Endocrine, paracrine and synaptic (Fig. 6).

The recent findings of gastrointestinal endocrine cells exhibiting endocrine and neuron-like characteristics support and revive the old hypothesis on the evolution of the neuroendocrine system of the gut (76). The observation that the mammalian gastrointestinal hormonal peptides occur in the CNS, but not in the gut of invertebrates (77-79), led to the hypothesis that the gastrointestinal endocrine cells of vertebrates originated in the nervous system of a common ancestor, and migrated during a later stage of evolution into the gut as scattered endocrine cells (76). 


\section{Interaction between diet and gastrointestinal cells}

As aforementioned, the composition of the diet with different proportions of carbohydrates, proteins and fats is a trigger for the release of different gut hormones into the lamina propria. Furthermore, the ingested foodstuffs act as prebiotics for the intestinal microbiota, and the byproducts of the bacteria trigger also the release of hormones from the gut endocrine cells.

It has been shown recently that a change in diet is accompanied by a change in the density of gastrointestinal cells (3-6). This could be due to an ingested foodstuff acting as a prebiotic for the intestinal bacteria with the associated bacterial byproducts. These bacterial byproducts may act on the stem cells and/or differentiation progenitors, resulting in changes in the stem cell clonogenic activity and/or differentiation progeny. Alternatively, these bacterial byproducts could act on mature gastrointestinal cells to favor the expression of specific hormones (Fig. 7). Thus, the change in the density of a certain endocrine cell type could be caused by switching to the expression of a different hormone.

\section{Conclusion}

The diet is important for regulating the functions of gastrointestinal endocrine cells. It not only regulates the release of hormones from these cells, but also affects their densities. The interaction between nutrients and gastrointestinal endocrine cells could be useful for the clinical management of several diseases, such as irritable bowel syndrome, obesity and diabetes (17,80-85).

\section{References}

1. El-Salhy M, Gilja OH, Gundersen D, Hatlebakk JG and Hausken T: Interaction between ingested nutrients and gut endocrine cells in patients with irritable bowel syndrome (Review). Int J Mol Med 34: 363-371, 2014.

2. Mittermaier C, Dejaco C, Waldhoer T, Oefferlbauer-Ernst A, Miehsler W, Beier M, Tillinger W, Gangl A and Moser G: Impact of depressive mood on relapse in patients with inflammatory bowel disease: A prospective 18-month follow-up study. Psychosom Med 66: 79-84, 2004.

3. Mazzawi T, Gundersen D, Hausken T and El-Salhy M: Increased gastric chromogranin A cell density following changes to diets of patients with irritable bowel syndrome. Mol Med Rep 10 2322-2326, 2014.

4. Mazzawi T, Gundersen D, Hausken T and El-Salhy M: Increased chromogranin A cell density in the large intestine of patients with irritable bowel syndrome after receiving dietary guidance. Gastroenterol Res Pract 2015: 823897, 2015.

5. Mazzawi T, Hausken T, Gundersen D and El-Salhy M: Effect of dietary management on the gastric endocrine cells in patients with irritable bowel syndrome. Eur J Clin Nutr 69: 519-524, 2014

6. Mazzawi T, Hausken T, Gundersen D and El-Salhy M: Normalization of large intestinal endocrine cells following dietary management in patients with irritable bowel syndrome. Eur J Clin Nutr 70: 175-178, 2016.

7. El-Salhy M, Seim I, Chopin L, Gundersen D, Hatlebakk JG and Hausken T: Irritable bowel syndrome: The role of gut neuroendocrine peptides. Front Biosci (Elite Ed) 4: 2783-2800, 2012.

8. El-Salhy M, Gundersen D, Hatlebakk JG and Hausken T: Irritable bowel syndrome: Diagnosis, pathogenesis and treatment options. Nova Science Publishers, Inc., New York, NY, 2012.

9. May CL and Kaestner KH: Gut endocrine cell development. Mol Cell Endocrinol 323: 70-75, 2010.

10. Gunawardene AR, Corfe BM and Staton CA: Classification and functions of enteroendocrine cells of the lower gastrointestinal tract. Int J Exp Pathol 92: 219-231, 2011.
11. El-Salhy M, Grimelius L, Wilander E, Ryberg B, Terenius L, Lundberg JM and Tatemoto K: Immunocytochemical identification of polypeptide YY (PYY) cells in the human gastrointestinal tract. Histochemistry 77: 15-23, 1983.

12. El-Salhy M, Gilja OH, Gundersen D, Hatlebakk JG and Hausken T: Duodenal chromogranin a cell density as a biomarker for the diagnosis of irritable bowel syndrome. Gastroenterol Res Pract 2014: 462856, 2014.

13. El-Salhy M, Gilja OH and Hausken T: Chromogranin A cells in the stomachs of patients with sporadic irritable bowel syndrome. Mol Med Rep 10: 1753-1757, 2014.

14. El-Salhy M, Mazzawi T, Gundersen D and Hausken T: Chromogranin A cell density in the rectum of patients with irritable bowel syndrome. Mol Med Rep 6: 1223-1225, 2012.

15. El-Salhy M, Lomholt-Beck B and Hausken T: Chromogranin A as a possible tool in the diagnosis of irritable bowel syndrome. Scand J Gastroenterol 45: 1435-1439, 2010.

16. El-Salhy M, Wendelbo IH and Gundersen D: Reduced chromogranin A cell density in the ileum of patients with irritable bowel syndrome. Mol Med Rep 7: 1241-1244, 2013.

17. El-Salhy M, Ostgaard H, Gundersen D, Hatlebakk JG and Hausken T: The role of diet in the pathogenesis and management of irritable bowel syndrome (Review). Int J Mol Med 29: 723-731, 2012.

18. El-Salhy M: Irritable bowel syndrome: Diagnosis and pathogenesis. World J Gastroenterol 18: 5151-5163, 2012.

19. Mawe GM, Coates MD and Moses PL: Review article: Intestinal serotonin signalling in irritable bowel syndrome. Aliment Pharmacol Ther 23: 1067-1076, 2006.

20. Wade PR, Chen J, Jaffe B, Kassem IS, Blakely RD and Gershon MD: Localization and function of a 5-HT transporter in crypt epithelia of the gastrointestinal tract. J Neurosci 16: 2352-2364, 1996.

21. Gershon MD and Tack J: The serotonin signaling system: From basic understanding to drug development for functional GI disorders. Gastroenterology 132: 397-414, 2007.

22. Gershon MD: 5-Hydroxytryptamine (serotonin) in the gastrointestinal tract. Curr Opin Endocrinol Diabetes Obes 20: 14-21, 2013.

23. Gershon MD: Serotonin is a sword and a shield of the bowel: Serotonin plays offense and defense. Trans Am Clin Climatol Assoc 123: 268-280, discussion 280, 2012.

24. El-Salhy M, Mazzawi T, Gundersen D, Hatlebakk JG and Hausken T: The role of peptide YY in gastrointestinal diseases and disorders (Review). Int J Mol Med 31: 275-282, 2013.

25. Dubrasquet M, Bataille D and Gespach C: Oxyntomodulin (glucagon-37 or bioactive enteroglucagon): A potent inhibitor of pentagastrin-stimulated acid secretion in rats. Biosci Rep 2: 391-395, 1982.

26. Schjoldager BT, Baldissera FG, Mortensen PE, Holst JJ and Christiansen J: Oxyntomodulin: A potential hormone from the distal gut. Pharmacokinetics and effects on gastric acid and insulin secretion in man. Eur J Clin Invest 18: 499-503, 1988.

27. Schjoldager B, Mortensen PE, Myhre J, Christiansen J and Holst JJ: Oxyntomodulin from distal gut. Role in regulation of gastric and pancreatic functions. Dig Dis Sci 34: 1411-1419, 1989.

28. Dakin CL, Small CJ, Batterham RL, Neary NM, Cohen MA, Patterson M, Ghatei MA and Bloom SR: Peripheral oxyntomodulin reduces food intake and body weight gain in rats. Endocrinology 145: 2687-2695, 2004.

29. Wynne K, Park AJ, Small CJ, Patterson M, Ellis SM, Murphy KG, Wren AM, Frost GS, Meeran K, Ghatei MA, et al: Subcutaneous oxyntomodulin reduces body weight in overweight and obese subjects: A double-blind, randomized, controlled trial. Diabetes 54: 2390-2395, 2005.

30. Camilleri M: Peripheral mechanisms in irritable bowel syndrome. N Engl J Med 367: 1626-1635, 2012.

31. Jianu CS, Fossmark R, Syversen U, Hauso $\varnothing$ and Waldum HL: A meal test improves the specificity of chromogranin A as a marker of neuroendocrine neoplasia. Tumour Biol 31: 373-380, 2010.

32. Seim I, El-Salhy M, Hausken T, Gundersen D and Chopin L: Ghrelin and the brain-gut axis as a pharmacological target for appetite control. Curr Pharm Des 18: 768-775, 2012.

33. Wang J, Cortina G, Wu SV, Tran R, Cho JH, Tsai MJ, Bailey TJ, Jamrich M, Ament ME, Treem WR, et al: Mutant neurogenin-3 in congenital malabsorptive diarrhea. N Engl J Med 355: 270-280, 2006.

34. Ghia JE, Blennerhassett P, Deng Y, Verdu EF, Khan WI and Collins SM: Reactivation of inflammatory bowel disease in a mouse model of depression. Gastroenterology 136: 2280-2288 e1-4, 2009. 
35. Spångéus A, Forsgren S and el-Salhy M: Does diabetic state affect co-localization of peptide $Y Y$ and enteroglucagon in colonic endocrine cells? Histol Histopathol 15: 37-41, 2000.

36. Pyarokhil AH, Ishihara M, Sasaki $\mathrm{M}$ and Kitamura $\mathrm{N}$ : The developmental plasticity of colocalization pattern of peptide YY and glucagon-like peptide-1 in the endocrine cells of bovine rectum. Biomed Res 33: 35-38, 2012.

37. Haroon E, Raison CL and Miller AH: Psychoneuroimmunology meets neuropsychopharmacology: Translational implications of the impact of inflammation on behavior Neuropsychopharmacology 37: 137-162, 2012.

38. El-Salhy M, Wilander E and Grimelius L: Immunocytochemical localization of gastric inhibitory peptide (GIP) in the human foetal pancreas. Ups J Med Sci 87: 81-85, 1982

39. Ghia JE, Li N, Wang H, Collins M, Deng Y, El-Sharkawy RT, Côté F, Mallet J and Khan WI: Serotonin has a key role in pathogenesis of experimental colitis. Gastroenterology 137: 1649-1660, 2009.

40. Dryden S, Wang Q, Frankish HM, Pickavance L and Williams G The serotonin (5-HT) antagonist methysergide increases neuropeptide Y (NPY) synthesis and secretion in the hypothalamus of the rat. Brain Res 699: 12-18, 1995.

41. Sandström O and El-Salhy M: Ageing and endocrine cells of human duodenum. Mech Ageing Dev 108: 39-48, 1999.

42. El-Salhy M: Ghrelin in gastrointestinal diseases and disorders: A possible role in the pathophysiology and clinical implications (Review). Int J Mol Med 24: 727-732, 2009.

43. Tolhurst G, Reimann F and Gribble FM: Intestinal sensing of nutrients. Handb Exp Pharmacol 209: 309-335, 2012.

44. Lee J, Cummings BP, Martin E, Sharp JW, Graham JL, Stanhope KL, Havel PJ and Raybould HE: Glucose sensing by gut endocrine cells and activation of the vagal afferent pathway is impaired in a rodent model of type 2 diabetes mellitus. Am J Physiol Regul Integr Comp Physiol 302: R657-R666, 2012.

45. Parker HE, Reimann F and Gribble FM: Molecular mechanisms underlying nutrient-stimulated incretin secretion. Expert Rey Mol Med 12: e1, 2010.

46. Raybould HE: Nutrient sensing in the gastrointestinal tract: Possible role for nutrient transporters. J Physiol Biochem 64: 349-356, 2008

47. San Gabriel A, Nakamura E, Uneyama H and Torii K: Taste, visceral information and exocrine reflexes with glutamate through umami receptors. J Med Invest 56: 209-217, 2009.

48. Rudholm T, Wallin B, Theodorsson E, Näslund E and Hellström PM: Release of regulatory gut peptides somatostatin, neurotensin and vasoactive intestinal peptide by acid and hyperosmolal solutions in the intestine in conscious rats. Regul Pept 152: 8-12, 2009.

49. Sternini C, Anselmi L and Rozengurt E: Enteroendocrine cells: A site of 'taste' in gastrointestinal chemosensing. Curr Opin Endocrinol Diabetes Obes 15: 73-78, 2008.

50. Sternini C: Taste receptors in the gastrointestinal tract. IV Functional implications of bitter taste receptors in gastrointestinal chemosensing. Am J Physiol Gastrointest Liver Physiol 292: G457-G461, 2007

51. Buchan AM: Nutrient tasting and signaling mechanisms in the gut III. Endocrine cell recognition of luminal nutrients. Am J Physiol 277: G1103-G1107, 1999.

52. Montero-Hadjadje M, Elias S, Chevalier L, Benard M, Tanguy Y, Turquier V, Galas L, Yon L, Malagon MM, Driouich A, et al: Chromogranin A promotes peptide hormone sorting to mobile granules in constitutively and regulated secreting cells: Role of conserved $\mathrm{N}$ - and C-terminal peptides. J Biol Chem 284 12420-12431, 2009.

53. Shooshtarizadeh P, Zhang D, Chich JF, Gasnier C, Schneider F, Haïkel Y, Aunis D and Metz-Boutigue MH: The antimicrobial peptides derived from chromogranin/secretogranin family, new actors of innate immunity. Regul Pept 165: 102-110, 2010.

54. Reber SO, Obermeier F, Straub RH, Falk W and Neumann ID: Chronic intermittent psychosocial stress (social defeat/overcrowding) in mice increases the severity of an acute DSS-induced colitis and impairs regeneration. Endocrinology 147: 4968-4976, 2006.

55. Milde AM and Murison R: A study of the effects of restraint stress on colitis induced by dextran sulphate sodium in singly housed rats. Integr Physiol Behav Sci 37: 140-150, 2002.

56. Furness JB, Kunze WA and Clerc N: Nutrient tasting and signaling mechanisms in the gut. II. The intestine as a sensory organ: Neural, endocrine, and immune responses. Am J Physiol 277: G922-G928, 1999.
57. Hassani H, Lucas G, Rozell B and Ernfors P: Attenuation of acute experimental colitis by preventing NPY Y1 receptor signaling. Am J Physiol Gastrointest Liver Physiol 288: G550-G556, 2005.

58. Cani PD, Everard A and Duparc T: Gut microbiota, enteroendocrine functions and metabolism. Curr Opin Pharmacol 13: 935-940, 2013.

59. Cani PD, Hoste S, Guiot Y and Delzenne NM: Dietary non-digestible carbohydrates promote L-cell differentiation in the proximal colon of rats. Br J Nutr 98: 32-37, 2007.

60. Petitto JM, Huang Z and McCarthy DB: Molecular cloning of NPY-Y1 receptor CDNA from rat splenic lymphocytes: Evidence of low levels of mRNA expression and [125I]NPY binding sites. J Neuroimmunol 54: 81-86, 1994

61. De la Fuente M, Bernaez I, Del Rio M and Hernanz A Stimulation of murine peritoneal macrophage functions by neuropeptide $\mathrm{Y}$ and peptide $\mathrm{YY}$. Involvement of protein kinase $\mathrm{C}$. Immunology 80: 259-265, 1993.

62. Shibata M, Hisajima T, Nakano M, Goris RC and Funakoshi K Morphological relationships between peptidergic nerve fibers and immunoglobulin A-producing lymphocytes in the mouse intestine. Brain Behav Immun 22: 158-166, 2008.

63. Painsipp E, Herzog H, Sperk G and Holzer P: Sex-dependent control of murine emotional-affective behaviour in health and colitis by peptide YY and neuropeptide Y. Br J Pharmacol 163: 1302-1314, 2011

64. Rindi G, Inzani F and Solcia E: Pathology of gastrointestinal disorders. Endocrinol Metab Clin North Am 39: 713-727, 2010.

65. Cummings DE and Overduin J: Gastrointestinal regulation of food intake. J Clin Invest 117: 13-23, 2007.

66. Bertrand PP: The cornucopia of intestinal chemosensory transduction. Front Neurosci 3: 48, 2009.

67. Bertrand PP and Bertrand RL: Serotonin release and uptake in the gastrointestinal tract. Auton Neurosci 153: 47-57, 2010.

68. El-Salhy M, Grimelius L, Wilander E, Abu-Sinna G and Lundqvist G: Histological and immunohistochemical studies of the endocrine cells of the gastrointestinal mucosa of the toad (Bufo regularis). Histochemistry 71: 53-65, 1981.

69. Sandstrom O: Age-related changes in the neuroendocrine system of the gut. Umea Univ Med Diss 617: 1-46, 1999.

70. Bohórquez DV, Chandra R, Samsa LA, Vigna SR and Liddle RA Characterization of basal pseudopod-like processes in ileal and colonic PYY cells. J Mol Histol 42: 3-13, 2011

71. Gustafsson BI, Bakke I, Hauso Ø, Kidd M, Modlin IM, Fossmark R, Brenna E and Waldum HL: Parietal cell activation by arborization of ECL cell cytoplasmic projections is likely the mechanism for histamine induced secretion of hydrochloric acid. Scand J Gastroenterol 46: 531-537, 2011.

72. Gustafsson BI, Bakke I, Tømmerås K and Waldum HL: A new method for visualization of gut mucosal cells, describing the enterochromaffin cell in the rat gastrointestinal tract. Scand J Gastroenterol 41: 390-395, 2006.

73. Pang XH, Li TK, Xie Q, He FQ, Cui J, Chen YQ, Huang XL and Gan HT: Amelioration of dextran sulfate sodium-induced colitis by neuropeptide $\mathrm{Y}$ antisense oligodeoxynucleotide. Int J Colorectal Dis 25: 1047-1053, 2010.

74. Bohórquez DV, Samsa LA, Roholt A, Medicetty S, Chandra R and Liddle RA: An enteroendocrine cell-enteric glia connection revealed by 3D electron microscopy. PLoS One 9: e89881, 2014.

75. Bohórquez DV, Shahid RA, Erdmann A, Kreger AM, Wang Y, Calakos N, Wang F and Liddle RA: Neuroepithelial circuit formed by innervation of sensory enteroendocrine cells. J Clin Invest 125: 782-786, 2015.

76. El-Salhy M: On the phylogeny of the gastro-entero-pancreatic (GEP) neuroendocrine system. Acta Uni Uppsal 385: 1-39, 1981.

77. El-Salhy M, Abou-el-Ela R, Falkmer S, Grimelius L and Wilander E: Immunohistochemical evidence of gastro-entero-pancreatic neurohormonal peptides of vertebrate type in the nervous system of the larva of a dipteran insect, the hoverfly, Eristalis aeneus. Regul Pept 1: 187-204, 1980.

78. El-Salhy M, Falkmer S, Kramer KJ and Speirs RD: Immunohistochemical investigations of neuropeptides in the brain, corpora cardiaca, and corpora allata of an adult lepidopteran insect, Manduca sexta (L). Cell Tissue Res 232: 295-317, 1983.

79. El-Salhy M, Falkmer S, Kramer KJ and Speirs RD: Immunocytochemical evidence for the occurrence of insulin in the frontal ganglion of a Lepidopteran insect, the tobacco hornworm moth, Manduca sexta L. Gen Comp Endocrinol 54: 85-88, 1984.

80. Mazzawi T, Hausken T, Gundersen D and El-Salhy M: Effects of dietary guidance on the symptoms, quality of life and habitual dietary intake of patients with irritable bowel syndrome. Mol Med Rep 8: 845-852, 2013. 
81. Ostgaard H, Hausken T, Gundersen D and El-Salhy M: Diet and effects of diet management on quality of life and symptoms in patients with irritable bowel syndrome. Mol Med Rep 5: 1382-1390, 2012.

82. García-Martínez JM, Chocarro-Calvo A, De la Vieja A and García-Jiménez C: Insulin drives glucose-dependent insulinotropic peptide expression via glucose-dependent regulation of FoxO1 and LEF1/ $\beta$-catenin. Biochim Biophys Acta 1839: 1141-1150, 2014

83. García-Martínez JM, Chocarro-Calvo A, Moya CM and García-Jiménez C: WNT/beta-catenin increases the production of incretins by entero-endocrine cells. Diabetologia 52: 1913-1924, 2009.
84. Freeland KR, Wilson C and Wolever TM: Adaptation of colonic fermentation and glucagon-like peptide-1 secretion with increased wheat fibre intake for 1 year in hyperinsulinaemic human subjects. Br J Nutr 103: 82-90, 2010.

85. Korner J, Bessler M, Inabnet W, Taveras C and Holst JJ: Exaggerated glucagon-like peptide-1 and blunted glucosedependent insulinotropic peptide secretion are associated with Roux-en-Y gastric bypass but not adjustable gastric banding. Surg Obes Relat Dis 3: 597-601, 2007. 